See discussions, stats, and author profiles for this publication at: https://www.researchgate.net/publication/306532427

\title{
Are you aware of what you are doing? Asking Italian hunters about an invasive alien species they are introducing
}

Article in Journal for Nature Conservation · August 2016

DOI: 10.1016/j.jnc.2016.08.003

\section{CITATIONS}

4

3 authors:

Jacopo Cerri

Institute for Environmental Protection and Research (ISPRA)

21 PUBLICATIONS 18 CITATIONS

SEE PROFILE

Elena Tricarico

University of Florence

117 PUBLICATIONS 1,798 CITATIONS

SEE PROFILE

Some of the authors of this publication are also working on these related projects:

Decapod fauna of the region Tuscany View project

Project INVASIVESNET View project
108

Marco Ferretti

Tuscany Region

33 PUBLICATIONS 67 CITATIONS

SEE PROFILE 
Title: "Are you aware of what you are doing? Asking Italian hunters about an invasive alien species they are introducing”

\section{Authors:}

- Jacopo Cerri, Scuola Superiore Sant'Anna, Istituto di Management, Piazza Martiri della Libertà 33, 56127, Pisa, Italy; email: j.cerri@santannapisa.it

- Marco Ferretti, Regione Toscana, settore Caccia e Pesca, Corso Gramsci 110, 51100, Pistoia, Italy; email: marco.ferretti@regione.toscana.it

- Elena Tricarico, Università degli Studi di Firenze, Dipartimento di Biologia, Via Romana 17, 50127, Firenze, Italy; email: elena.tricarico@unifi.it

\section{Abstract}

The human-driven spread of Invasive Alien Species is a major concern for conservation biologists. Since hunters are spreading invasive Eastern cottontails (Sylvilagus floridanus) in Italy, we investigated their beliefs about the species through semi-qualitative questionnaires in Tuscany, an area where cottontails have been occurring since 2000. Most respondents regarded invasive cottontails as a subspecies of the native European wild rabbit. Native European hares were highly valued as a game and perceived as a declining species, whereas no clear reason explained the hunting of cottontails and their population trend. We found no relationship between perceiving hares as a declining game and supporting the introduction of cottontails, or hunting cottontails. Respondents supported or opposed the eradication of cottontails according to their beliefs about the negative impact of the species over native hares. Hunters seem to have unclear ideas about cottontails and their impact and hold stable and positive attitudes towards the conservation of native hares. Cottontails are unlikely to replace hares as a game in the short term but may become a substitute game in case of a severe reduction in the abundance of hares. Our results could enable 
wildlife managers to plan eradication schemes to counteract invasive cottontails without fearing any strong opposition by hunters, provided that effective conservation plans are available for native game species. Hunters could also be engaged in large-scale monitoring programs based on hunting bags, as an encouraging number of respondents record killed cottontails on their hunting card. Future studies should broaden the investigation of hunters' and angler's perception of invasive alien species, as these two leisure activities are responsible for their spread worldwide.

\section{Introduction}

Invasive Alien Species (IAS) are a major issue for conservation biologists, being one of the main causes behind the biodiversity loss worldwide and because they are responsible for massive changes in ecosystems structure and functionality (Simberloff et al., 2013). The costs associated to IAS have been estimated as 120 billion \$ per year in the US (Pimentel, Zuniga, \& Morrison, 2005) and about 12-20 billion $€$ per year in the European Union (Kettunen et al., 2009).

Despite the majority of IAS being accidentally spread through global commerce or transport (Hulme, 2009), some taxa are deliberately introduced in the environment for recreational purposes. Some well-known cases include freshwater fish used in sport angling (Cambray, 2003; Hargrove, Weyl, Allen, \& Deacon, 2015), as well as game birds (Lockwood, 1999) and mammals (Dolman \& Wäber, 2008) for hunting. Hunting and angling are two leisure activities with a strong cultural component and the role of hunters and anglers in contemporary society is quickly changing. Previous research has demonstrated that cultural factors affect several attributes of hunters, especially their recruitment (Hansen, Peterson, \& Jensen, 2012). Furthermore, there is growing evidence that the gap between the value orientation of hunters and that of non-hunters is increasing, at least in Western Countries, where the majority of human population is shifting towards a nonconsumptive perspective of wildlife (Manfredo, Teel, \& Henry, 2009; Manfredo, 2008). Such a change is likely to result in deep transformations at the societal and the institutional level, including 
the management of native and invasive wildlife.

To address the issue of recreational-introduced IAS, wildlife managers have to access information about the stakeholders involved in spreading IAS. Otherwise, they may introduce ineffective and socially unacceptable management actions (McNeely, 2001). A whole spectrum of approaches is available to surveyors to acquire such information. At one end of the spectrum, in-depth qualitative interviews or questionnaires are a valuable tool to define all the dimensions of a problem and, in general, to explore issues where no prior idea exists in the mind of the surveyors. At the opposite, once surveyors are certain about what has to be measured, structured quantitative questionnaires can be implemented, to measure specific constructs and to predict stakeholders' behaviour through quantitative analysis. Semi-qualitative questionnaires lie in the middle of the spectrum, enabling surveyors to collect structured information for quantitative analysis meanwhile acquiring additional details through open-ended questions (Vaske, 2008).

The Eastern cottontail (Sylvilagus floridanus) is a North American lagomorph, which has been repeatedly introduced in Northern and Central Italy in the last decades. Its first intro duction dates back to 1960 in Piedmont (Silvano, Acquarone, \& Cucco, 2000), therefore the species has expanded its distribution in the neighbouring areas of the Po plain (Bertolino, Ingegno, \& Girardello, 2011). Established populations are now widespread in Central Italy, notably in Northern Tuscany, Umbria and Latium (Capizzi, Mortelliti, Amori, Colangelo, \& Rondinini, 2012). Even if previous works highlighted the lack of competition between cottontails and the native European hare (Lepus europaeus) (Bertolino, Di Montezemolo, \& Perrone, 2013; Vidus-Rosin et al., 2011), other studies demonstrated the potential role of cottontails as a vector for several pathologies. Cottontails can carry zoonoses (Zanet, Palese, Trisciuoglio, Alonso, \& Ferroglio, 2013), fungal infections (Gallo, Tizzani, Peano, Rambozzi, \& Meneguz, 2005; Tizzani et al., 2007) and virus like the European Brown Hare Syndrome Virus (EBHSV) (Lavazza et al., 2015). 
The Italian legislation about hunting relies on a general framework set by the national law on wildlife (n.157/92), upon which local dispositions are nested. Currently, most of the provinces where cottontails occur have enforced numerical control schemes to contain the species, based on authorized shooting sessions during the year. Furthermore, some regions like Tuscany removed the upper limit to the daily hunting bag of cottontails and the obligation for hunters to record killed individuals. Such measures aimed to increase cottontail culling by reducing hunters' effort to record individuals.

Practical evidence, altogether with the highly fragmented distribution of cottontails in Italy and the low dispersal of the species, indicates a series of repeated introductions in the environment. Hunters regularly purchase cottontails at local game fairs and release them as a game (a picture showing this phenomenon is available in Supplementary material). Paradoxically, as professional hunting does not exist in Italy, hunters are also engaged in control programs for cottontails. Understanding their knowledge and beliefs about cottontails could guide wildlife managers in developing feasible management options for the species.

This work has multiple goals; firstly, it aims to provide qualitative insights about hunters' knowledge and beliefs about introduced cottontails and about their relationships with the native European hare. Secondly, it aims to investigate whether hare hunters have adopted cottontails as the main game prey. Finally, it aims to highlight feasible solutions for monitoring the spread of cottontails and for engaging hunters in cottontail management.

\section{Materials and methods}

From August 2014 to January 2015, we surveyed hunters at 17 municipal offices in Tuscany, Italy,

(Fig. 1) during the withdrawal or the delivery of their hunting licence. Municipal employees asked hunters to fill in the questionnaire once they had withdrawn or delivered their licence at the municipal desk. We had contacted municipal employees in advance by phone, explaining the aims 
of the study and providing them directions for distributing the forms to hunters. Since participation in the survey was voluntary, questionnaires had been designed to take a maximum of 5 min to complete, placing minimum effort on respondents. Once respondents filled the questionnaire, they could put it directly into a sealed urn, to ensure anonymity. Open-ended questions were used to explore topics over which we had no strong a-priory knowledge. Binary questions and Likert scales were adopted to express respondents' beliefs over a range of more known topics.

Questionnaires were structured in five different sections. A first section collected the demographic features of respondents and defined the time and date of the questionnaire. A second section of the questionnaire was aimed at classifying hunters according to the features of their hunting experience and their general beliefs towards game management. The third section of the survey focused on hares and cottontail hunting and was aimed at identifying the favourite game species between the two lagomorphs, as well as hunter's beliefs about the population trends of the two species. The fourth section explored respondents' knowledge of the biology of cottontails and their beliefs about the relationships between hares and cottontails. The final section explored respondents' attitudes towards the management of cottontails. A table summarizing the questionnaire is shown in Table 1. At the end of the survey, we gathered 292 questionnaires. Despite municipal offices receiving some questionnaires prior to the beginning of the survey, municipal employees often printed further copies on request and did not record those hunters who refused to take part in the survey. Therefore, it was impossible to estimate the rejection rate or to assess the major socio-demographic features of non-respondents. We discarded 32 questionnaires due to the high number of unanswered questions and we retained 260 questionnaires for data analysis. According to the last available estimates from 2010, 96970 hunters occur in the study area. Therefore, our sample corresponded to $0.3 \%$ of the total population.

Both sample size and non-random sampling did not allow us to make formal inference about the target population through statistical estimators. However, our questionnaire had an exploratory 
nature and, as we did not aim to make formal inference about target population, we deemed its sample size and the number of municipalities covered suitable to meet our study aims.

A final set of 19 variables was coded (Table 2). We grouped open-ended questions in qualitative classes and treated them as non-ordinal factors. We converted multiple-choice questions in vectors of binary variables. To summarize the information about respondents' attitudes towards the management of cottontails we aggregated the dichotomous questions in the last section of the survey into another binary vector. Since $86 \%$ of respondents declared to hunt in their neighbouring municipalities, we grouped respondents in six geographical areas, corresponding to six clusters of neighbouring municipalities. This grouping enabled us to test for local differences in hunters' beliefs about cottontails, one of the aims of this study.

We performed the $\chi^{2}$ test for homogeneity to highlight differences in the perceived population trends of invasive cottontails and native hares. We adopted the $x^{2}$ test for independence to measure the relationship between individual beliefs over a negative impact of cottontails and the support given to their eradication. We also tested the independence between the perceived decline of native hares and attitudes towards hunting or releasing cottontails.

We explored the geographic differences in hunters' beliefs about cottontails and hares with three different approaches. We used the $x^{2}$ test for homogeneity to compare the proportion of respondents who believed cottontails were a subspecies of the European wild rabbit, as well as the proportion of respondents who believed in some kind of negative impact of cottontails on the environment. We compared geographical differences in respondents' beliefs of a negative relationship between cottontails and native hares by performing One-Way ANOVA and Tukey post-hoc test with Bonferroni's correction on the scoring obtained from a Likert scale in the fourth section of the questionnaire. Before performing the ANOVA, we checked the normal distribution of the scoring through quantile analysis and the homogeneity of variances with the Bartlett's test. Finally, we compared multiple-choice answers of hunters from the same area with those of hunters from 
different geographical areas through the Sørensen’s coefficient of similarity (Andreu \& Vilà, 2010). Multiple-choice answers, coded as binary vectors, were used to express respondents' reason for hunting hares and cottontails, respondents' beliefs about the limiting factors for hare populations and respondents' attitudes towards the management of cottontails. The average Sørensen's coefficient thus expressed respondents' consensus over a certain topic and significant differences between inter- and intra-area coefficients were used as a measure of geographical differentiation. Nonparametric Mann Whitney test was used to test for significant differences between coefficients. The binary vectors in the questionnaires from Lucca and Pisa $(n=21)$ were not compared, due to the high proportion of missing data. Statistical analysis and graphs were performed with R 3.1.2 (R Core Team, 2016).

\section{Results}

The mean age of respondents was 59.4 years and the age distribution of our sample did not significantly differ from the age distribution of hunters in the study area $\left(\chi^{2}=3.95, p>0.05\right)$. Despite all the respondents being men, this was not considered a bias: among the hunters in the study area the number of women who hunt is far less than $1 \%$, and official estimates about the gender of hunters have not even been elaborated by the Regional office. The majority of respondents declared to know the Eastern cottontail (83\%), even if the average proportion of unanswered questions about the biology of the species was high (29\%, Table 2). Most respondents did not identify the cottontails as a self-standing game species (18\%), but mainly as a subspecies of the European wild rabbit $(60.6 \%)$, as a subspecies of the European hare (16\%) or as a hybrid between rabbits and hares (5\%). A remarkable proportion of respondents (30\%) included cottontails among autochthonous wildlife. Few hunters filled the open-ended question about the geographical origin of cottontails (18\%) and a handful of them correctly answered such question (7\%). A great proportion of respondents does not eat killed cottontails (37\%). A significant proportion of 
respondents (41\%) supported the eradication of cottontails and $12 \%$ of respondents provided a reason for their answer. Competition with native hares was the major reason for eradicating cottontails, followed by crop damaging, the idea that invasive species should be removed as such, the risk of disease transmission to native hares and the fear of a high density of animals. On the other hand, $31 \%$ of respondents opposed the eradication of cottontails and $18 \%$ of them provided motivation for their answer. Being a game species was the main reason, followed by the idea that cottontails had been introduced too long ago and any attempt to remove them would have been ineffective, and by the lack of any impact of cottontails. Two respondents claimed that cottontails should not have been eradicated as they were a native species. Despite the lack of legal obligations, $50 \%$ of respondents declared to record culled cottontails on their hunting card.

Native hares were preferred to invasive cottontails by $67 \%$ of respondents, whereas $12 \%$ only preferred cottontails and $19 \%$ were unable to choose a favourite game between the two lagomorphs. Respondents perceived the population trends of the two species in different ways $\left(\chi^{2}=87.52\right.$, $\mathrm{p}<$ 0.01) (Fig. 2). The individual support given to the eradication of cottontails and individual beliefs about any possible negative impacts related to their introduction were linked $\left(\mathrm{X}^{2}=14.02, \mathrm{p}<0.01\right)$ (Fig. 3). On the other hand, the perceived population decline of native hares were independent from individual attitudes about releasing cottontails as a game $\left(x^{2}=1.41, \mathrm{p}>0.05\right)$ or from hunting cottontails $\left(\chi^{2}=1.54, \mathrm{p}>0.05\right)$ (Fig. 4).

The $x^{2}$ test for homogeneity revealed significant differences in the proportion of respondents who identified cottontails as a subspecies of the European wild rabbit $\left(x^{2}=19.6, \mathrm{p}<0.01\right)$, between the various geographical areas. We also found significant differences in the proportion of respondents who believed in a negative ecological impact of cottontails $\left(x^{2}=31.79, p<0.01\right)$ (Fig. 5). Respondents' beliefs about a negative impact of cottontails on native hares were homogeneous between the various areas $\left(x^{2}=7.76, \mathrm{p}>0.05\right)$ and followed a normal distribution. The One-Way ANOVA revealed a significant difference in the average scoring of respondents from two of the six 
areas $(\mathrm{p}<0.01)$ (Table 3). Hunters declared to hunt hares due to the demanding hunting technique and the satisfaction they received (Sørensen's coefficient $=0.84 \pm 0.11$ ). On the other hand, they did not have any strong reason to hunt cottontails (Fig. 6). We found no significant differences between the different areas. We found a low consensus over the factors which were supposed to negatively affect hares (Sørensen's coefficient $=0.27 \pm 0.42$ ). Despite significantly different, the average coefficient of hunters from the same area (Sørensen's coefficient $=0.28 \pm 0.43$ ) was lower than the average coefficient obtained by comparing hunters from different areas (Sørensen’s coefficient = $0.33 \pm 0.44$ ). This contradicted our initial hypothesis of a higher consensus shared by hunters from the same geographical zone. We found a low consensus about the management of cottontails (Sørensen’s coefficient $=0.13 \pm 0.25$ ) and no signifiçant differences between inter- and intra-area coefficients.

\section{Discussion}

Our results pointed out a lack of knowledge of respondents about the geographical origin and the biology of cottontails. This is somehow surprising, as respondents were hunters, a social group who deliberately purchases and releases cottontails for hunting.

The most confusing aspect seems to be the scientific status given to cottontails. Hunters regard cottontails as a subspecies of the European wild rabbit and not as a self-standing lagomorph species. However, the proportion of hunters who classified cottontails as rabbits varied between the different areas and this indicates a low agreement on the nature of cottontails. Previous works highlighted the potential of indirect sources of information, like web forums (Banha, Ilhéu, \& Anastácio, 2015), ecommerce websites (Mazza et al., 2015) and sport events (Hargrove et al., 2015) to monitor the introduction of new species in the environment. We are sceptical towards such approaches to monitor the colonization of Italy by cottontails, as hunters may misclassify the species with native rabbits. Furthermore, as we mentioned in the introduction, domestic rabbits are passed-of as Eastern 
cottontails at local game fairs and this could further lower the quality of such information. On the other hand, the proportion of respondents who record culled cottontails on their hunting booklet (50\%) was much higher than what we expected prior to the study. In fact, we had hypothesized that some respondents would have not revealed their hunting behaviour about cottontails, as they could have been uncertain about potential sanctions (Krumpal, 2013; Nuno \& St John, 2015). The fact that $50 \%$ of respondents actually declared to record killed cottontails is encouraging: as no largescale survey exists for the Eastern cottontail, in our opinion hunting bags may be an effective tool to monitor its colonization of new areas and its population dynamics, once hunters have been trained to discriminate the species from wild and domestic rabbits. Hunting statistics have been widely adopted to monitor long-term population dynamics of wildlife (Myrberget, 1988) and they have been applied to Eastern Cottontail population modelling (Mankin \& Warner, 1999). As changes in the current regional law are not foreseen in the near future, properly planned dissemination initiatives may encourage hunters to record culled cottontails, increasing the availability of data about the species. Previous research has shown that providing information about the scientific and the managerial importance of wildlife population monitoring is crucial to engage hunters in longterm game monitoring schemes (Singh, Danell, Edenius, \& Ericsson, 2014).

Hunters seem to be unaware of IAS and their related issues, as a high proportion of respondents included cottontails among native wildlife and many of them did not answer the question at all (53\%). Therefore, terms like "invasive”, "native” or "autochthonous” could have been misused and those hunters who supported the eradication of cottontails due to their "invasiveness" $(n=15)$ may actually regard cottontails as a general pest and not as an alien mammal species. Hunters are also unaware of the potential negative impacts of alien cottontails and their views are in contrast with scientific evidence. While a significant proportion of respondents (35\%) regarded diseases as a major threat for hares and previous studies highlighted the role of cottontails as vectors for several pathogens, few hunters $(n=10)$ were actually motivated to eradicate cottontails for sanitary 
reasons. Furthermore, while previous studies showed the lack of any competition between hares and cottontails (Bertolino et al., 2013; Vidus-Rosin et al., 2011), hunters believe that the worst consequence of introducing cottontails is their competition with native hares for habitat of trophic resources. This lack of knowledge about IAS-related issues and potential impacts of cottontails reflects a scarce dissemination of research results from researchers to the hunting community. Freely available information has been found to be an important tool to inform stakeholders over IAS (Bayliss, Wilcox, Stewart, \& Randall, 2012; Vanderhoeven et al., 2011), provided that informative campaigns are tailored (García-Llorente, Martín-López, González, Alcorlo, \& Montes, 2008). Furthermore, the social representation of IAS is partly driven by the perception of their environmental impacts (Selge \& Fischer, 2011). Considered that the support for the eradication of cottontails was related to hunters' beliefs about their negative impacts on native hares, we suggest that informing hunters about the possible disease transmission from cottontails to hares may be an effective way to raise their awareness and to engage them in lethal control programs.

The majority of hunters declared to hunt hares and explained their choice with clear arguments, while few hunters explicitly pursue cottontails and without any clear reason. Such fidelity to hares may explain why believing that hares are declining does not generally make respondents more favourable to release cottontails in the environment nor to select cottontails as a game. Hunters generally agree in defining hares as a declining species, while they do not agree over the population trend of cottontails. Such differences in hunters' certainties about the two species are not surprising: hunting is a leisure activity with a strong cultural component and embedding environmental changes in recreational practice might need time. After all, the European hare is a flagship species of extensive croplands and a traditional game in the study area (Santilli, 2007), whereas cottontails have being introduced in the last 15 years only and are still poorly known by hunters, as we saw before. We were able to find two studies only, examining the drivers behind the selection of introduced prey species, among hunters or anglers. In a recent work, Carvalho et al. (2014) explored 
the hunting of invasive mammals on the Island of Saõ Tomé, finding that the main reason behind invasive feral pigs hunting was self-consumption or meat trading to neighbours, whereas birds were hunted mostly because of the high demand placed by restaurants. In another study (Desbiez, Keroughlian, Piovezan, \& Bodment, 2011), researchers found that the motivations behind feral pig hunting in the Pantanal (Brasil) were clear and well defined among local communities of ranchers: feral pigs have become the main game species, because they are easy to hunt, constantly available and provide meat and animal fat for cooking. Despite the two papers analysing the hunting of IAS in developing countries, we agree with the authors that IAS may become future game species due to their economic potential. As the reproductive rate and the ecological adaptability are two key features of IAS (Kolar \& Lodge, 2001), future hunters may find it easier and more convenient to pursue and manage introduced game, like cottontails, instead of native game species. This could be reasonable if we consider that small game hunters in Mediterranean Europe are characterized by low income (Dickson et al., 2009). Future studies could adopt approaches aimed at identifying the cost-opportunity of IAS hunting and angling, as some authors have previously done with poaching in developing countries (Moro et al., 2013).

No clear picture is available about geographical differences in hunters' beliefs about invasive cottontails. Respondents from different zones had different ideas about the negative impact of cottontails, nevertheless the Sørensen’s similarity index failed to detect geographical differences in all the three multiple-choice questions where it was applied. Moreover, the results about the population decline of native hares contradicted the initial hypothesis of a higher agreement between hunters from the same area. If we consider that mentoring and the role of friends and relatives are crucial for hunter recruitment in Western countries (Hayslette, Armstrong, \& Mirarchi, 2001; Ryan \& Shaw, 2011), it is surprising that hunters from the same area do not show more similar ideas than hunters coming from different geographical zones. In Europe hunting is a traditional activity with a strong cultural component: cultural factors, for example, seem to explain differences in the 
harvesting season of Red deer (Cervus elaphus) among various European countries (Milner et al., 2006), as well as differences in prey selection between local and foreign Roe deer (Capreolus capreolus) stalkers (Mysterud, Tryjanowski, \& Panek, 2006). One possible explanation for these local differences could be that Eastern cottontails have been introduced at different years in the various geographical areas. Because of this, some respondents could not have had enough time to elaborate individual beliefs about the species and the consequences of its introduction. Another possible explanation may lie in the approach we used: despite previous works having adopted the Sørensen’s similarity index (Andreu \& Vilà, 2010), the comparison of multiple-choice questions may be refined by adopting a different index or by applying Cluster Analysis and latent variable analysis to segment the various groups of cottontail hunters (García-Llorente et al., 2008; Ward, Stedman, Luloff, Shortle, \& Finley, 2008).

\section{Conclusions}

This paper pinpoints several aspects related to the perception of an invasive species by the stakeholders who are deliberately introducing it in the environment.

Although we gathered some first insights about the perception of cottontails by hunters, future surveys should be designed to account for possible distortions in the answers caused by voluntary participation. Statistical techniques, like the Randomized Response Technique (Krumpal, 2013; Solomon, Gavin, \& Gore, 2015), may be adopted to estimate the risk of non-compliance with existing regulations about game restocking. Furthermore psychological frameworks, such as the Theory of Planned Behaviour (Manfredo, 2008), or classification trees (Drake, Mercader, Dobson, \& Mandrak, 2015) could be used to better understand the drivers of cottontail introduction. From our survey, we found that hunters do not know the biology and the invasive potential of cottontails. So far, cottontails are not replacing native hares as a game, as hares are still regarded as a valuable prey by hunters. However, the lack of any strong motivation behind the hunting of cottontails might 
make them a substitute game for hares in the near future, if the populations of native hares undergo a severe reduction in their numbers. We suggest using the positive attitudes of respondents towards native hares, together with the power of perceived IAS harmfulness (Selge, Fischer, \& Van der Wal, 2011) to engage hunters in the eradication of cottontails. Dissemination initiatives and specific conferences with researchers and managers may be promoted, to provide information about cottontails and their potential ecological impacts as well as to promote the European code of conduct of hunting and IAS (Monaco, Genovesi, \& Middleton, 2013). More over, promoting the recording of cottontails on the hunting card may enable wildlife managers to monitor the population trend of the species on a large geographical scale. Despite several IAS species having been introduced for sport angling or hunting, to the best of our knowledge no studies addressed hunters' or anglers' perception of IAS related issues. Because of the potential application of our results to IAS management, we are confident that this work will encourage other researchers to fill such gap in human dimension research.

\section{Acknowledgments}

We would like to express our gratitude to the Province of Pistoia and to all the municipal offices engaged in the distribution of the questionnaire.

\section{References}

Andreu, J., \& Vilà, M. (2010). Risk analysis of potential invasive plants in Spain. Journal for Nature Conservation, 18, 34-44. http://dx.doi.org/10.1016/j.jnc.2009.02.002

Banha, F., Ilhéu, M., \& Anastácio, P. M. (2015). Angling web forums as an additional tool for detection of new fish introductions: The first record of Perca fluviatilis in continental Portugal. Knowledge and Management of Aquatic Ecosystems, 416(3). 
Bayliss, H. R., Wilcox, A., Stewart, G. B., \& Randall, N. P. (2012). Does research information meet the needs of stakeholders? Exploring evidence selection in the global management of invasive species. Evidence \& Policy: A Journal of Research, Debate and Practice, 8(1), 37-56.

Bertolino, S., Ingegno, B., \& Girardello, M. (2011). Modelling the habitat requirements of invasive Eastern Cottontail (Sylvilagus floridanus) introduced to Italy. European Journal of Wildlife Research, 57, 267-274. http://dx.doi.org/10.1007/s10344-010-0422-9

Bertolino, S., Di Montezemolo, N. C., \& Perrone, A. (2013). Habitat use of coexisting introduced eastern cottontail and native European hare. Mammalian Biology, 78, 235-240. http://dx.doi.org/10.1016/j.mambio.2013.02.002

Cambray, J. A. (2003). Impact on indigenous species biodiversity caused by the globalisation of alien recreational freshwater fisheries. Aquatic biodiversity. pp. 217-230. Netherlands: Springer.

Capizzi, D., Mortelliti, A., Amori, G., Colangelo, P., \& Rondinini, C. (2012). I mammiferi del lazio.. http://www.arplazio.it/schede extra\&sx-pp+id pp-46+id settore-3+id-2891.htm Accessed 20.06.16

Carvalho, M., Palmeirim, J. M., Rego, F. C., Sole, N., Santana, A., \& Fa, J. E. (2014). What motivates hunters to target exotic or endemic species on the island of São Tomé, Gulf of Guinea. Oryx, 49(2), 278-286.

Desbiez, A. L. J., Keroughlian, A., Piovezan, U., \& Bodment, R. E. (2011). Invasive species and bushmeat hunting contributing to wildlife conservation: The case of feral pigs in a Neotropical wetland. Oryx, 45(01), 78-83.

Dickson, B., Hutton, J., \& Adams, W. A. (Eds.). (2009). Recreational hunting, conservation and rural livelihoods: science and practice. John Wiley \& Sons.

Dolman, P. M., \& Wäber, K. (2008). Ecosystem and competition impacts of introduced deer. Wildlife Research, 35(3), 202-214. 
Drake, D. A. R., Mercader, R., Dobson, T., \& Mandrak, N. E. (2015). Can we predict risky human behaviour involving invasive species? A case study of the release of fishes to the wild. Biological Invasions, 17(1), 309-326.

Gallo, M. G., Tizzani, P., Peano, A., Rambozzi, L., \& Meneguz, P. G. (2005). Eastern cottontail (Sylvilagus floridanus) as carrier of dermatophyte fungi. Mycopathologia, 160, 163-166. http://dx.doi.org/10.1007/s11046-005-6619-x

García-Llorente, M., Martín-López, B., González, J. A., Alcorlo, P., \& Montes, C. (2008). Social perceptions of the impacts and benefits of invasive alien species: Implications for management. Biological Conservation, 141(12), 2969-2983.

Hansen, H. P., Peterson, M. N., \& Jensen, C. (2012). Demographic transition among hunters: A temporal analysis of hunter recruitment dedication and motives in Denmark. Wildlife Research, 39(5), 446-451.

Hargrove, J. S., Weyl, O. L., Allen, M. S., \& Deacon, N. R. (2015). Using tournament angler data to rapidly assess the invasion status of alien sport fishes (Micropterus spp.) in Southern Aafrica. PLoS One, 10(6), e0130056.

Hayslette, S. E., Armstrong, J. B., \& Mirarchi, R. E. (2001). Mourning dove hunting in Alabama: Motivations, satisfactions, and sociocultural influences. Human Dimensions of Wildlife, 6(2), 8195.

Hulme, P. E. (2009). Trade, transport and trouble: Managing invasive species pathways in an era of globalization. Journal of Applied Ecology, 46(1), 10-18.

Kettunen, M., Genovesi, P., Gollasch, S., Pagad, S., Starfinger, U., ten Brink, P., et al. (2009). Technical support to EU strategy on invasive species (IAS) - Assessment of the impacts of IAS in Europe and the EU. Final report to the European Commission, Institute for European Environmental Policy (IEEP), Brussels, Belgium., 40 pp. + Annexes. 
Kolar, C. S., \& Lodge, D. M. (2001). Progress in invasion biology: Predicting invaders. Trends in Ecology \& Evolution, 16(4), 199-204.

Krumpal, I. (2013). Determinants of social desirability bias in sensitive surveys: A literature review. Quality \& Quantity, 47(4), 2025-2047.

Lavazza, A., Cavadini, P., Barbieri, I., Tizzani, P., Pinheiro, A., Abrantes, J., et al.(2015). Field and experimental data indicate that the eastern cottontail (Sylvilagus floridanus) is susceptible to infection with European brown hare syndrome (EBHS) virus and not with rabbit haemorrhagic disease (RHD) virus. Veterinary Research, 46(13), 1. http://dx.doi.org/10.1186/s13567-015-0149-4 Lockwood, J. L. (1999). Using taxonomy to predict success among introduced avifauna: Relative importance of transport and establishment. Conservation Biology, 13(3), 560-567.

Manfredo, M. J., Teel, T. L., \& Henry, K. L. (2009). Linking society and environment: A multilevel model of shifting wildlife value orientations in the western United States. Social Science Quarterly, 90(2), 407-427.

Manfredo, M. J. (2008). Who cares about wildlife? Springer.

Mankin, P. C., \& Warner, R. E. (1999). A regional model of the eastern cottontail and land-use changes in Illinois. The Journal of Wildlife Management, 63(3), 956-963.

Mazza, G., Aquiloni, L., Inghilesi, A. F., Giuliani, C., Lazzaro, L., Ferretti, G., et al. (2015). Aliens just a click away: The online aquarium trade in Italy. Management of Biological Invasions, 6(3), 253-261.

McNeely, J. A. (2001). The great reshuffling: human dimensions of invasive alien species. IUCN. www.vliz.be/imisdocs/publications/142047.pdf

Milner, J. M., Bonenfant, C., Mysterud, A., Gaillard, J. M., Csányi, S., \& Stenseth, N. C. (2006). Temporal and spatial development of red deer harvesting in Europe: Biological and cultural factors. Journal of Applied Ecology, 43(4), 721-734. 
Monaco, A., Genovesi, P., \& Middleton, A. (2013). European code of conduct on hunting and IAS. Council of Europe., 26 pp.

Moro, M., Fischer, A., Czajkowski, M., Brennan, D., Lowassa, A., Naiman, L. C., et al. (2013). An investigation using the choice experiment method into options for reducing illegal bushmeat hunting in western Serengeti. Conservation Letters, 6(1), 37-45.

Myrberget, S. (1988). Hunting statistics as indicators of game population size and composition. Statistical Journal of the United Nations Economic Commission for Europe, 5(3), 289-301.

Mysterud, A., Tryjanowski, P., \& Panek, M. (2006). Selectivity of harvesting differs between local and foreign roe deer hunters: Trophy stalkers have the first shot at the right place. Biology Letters, 2(4), 632-635.

Nuno, A., \& St John, F. A. (2015). How to ask sensitive questions in conservation: A review of specialized questioning techniques. Biological Conservation, 189, 5-15.

Pimentel, D., Zuniga, R., \& Morrison, D. (2005). Update on the environmental and economic costs associated with alien-invasive species in the United States. Ecological Economics, 52, 273-288.

R Core Team (2016). R: A language and environment for statistical computing. R Foundation for Statistical Computing, Vienna, Austria. URL https://www.R-project.org/.

Ryan, E. L., \& Shaw, B. (2011). Improving hunter recruitment and retention. Human Dimensions of Wildlife, 16(5), 311-317.

Santilli, F. (2007). Factors affecting brown hare (Lepus europaeus) hunting bags in Tuscany region (central Italy). Hystrix, the Italian Journal of Mammalogy, 17(2), 143-153.

Selge, S., \& Fischer, A. (2011). How people familiarize themselves with complex ecological concepts-Anchoring of social representations of invasive non-native species. Journal of Community \& Applied Social Psychology, 21(4), 297-311. 
Selge, S., Fischer, A., \& Van der Wal, R. (2011). Public and professional views on invasive nonnative species-A qualitative social scientific investigation. Biological Conservation, 144(12), 3089-3097.

Silvano, F., Acquarone, C., \& Cucco, M. (2000). Distribution of the eastern cottontail Sylvilagus floridanus in the province of Alessandria. Hystrix the Italian Journal of Mammalogy, 11(2), 75-78.

Simberloff, D., Martin, J.-L., Genovesi, P., Maris, V., Wardle, D. A., Aronson, J., et al. (2013). Impacts of biological invasions: What's what and the way forward. Trends in Ecology and Evolution, 28, 58-66.

Singh, N. J., Danell, K., Edenius, L., \& Ericsson, G. (2014). Tackling the motivation to monitor: Success and sustainability of a participatory monitoring program. Ecology and Society, 19(4), 7.

Solomon, J. N., Gavin, M. C., \& Gore, M. L. (2015). Detecting and understanding non-compliance with conservation rules. Biological Conservation, 189, 1-4. http://dx.doi.org/10.1016/j.biocon.2015.04.028

Tizzani, P., Gallo, M. G., Peano, A., Min, A. M., Pleite, C. M. C., \& Meneguz, P. G. (2007). Dermatophytosis caused by Microsporum canis in Eastern cottontail (Sylvilagus floridanus). European Journal of Wildlife Research, 53, 238-240. http://dx.doi.org/10.1007/s10344-007-0088-0 Vanderhoeven, S., Piqueray, J., Halford, M., Nulens, G., Vincke, J., \& Mahy, G. (2011). Perception and understanding of invasive alien species issues by nature conservation and horticulture professionals in Belgium. Environmental Management, 47(3), 425-442.

Vaske, J. J. (2008). Survey research and analysis: applications in parks, recreation and human dimensions. State College, PA: Venture Publishing.

Vidus-Rosin, A., Meriggi, A., Cardarelli, E., Serrano-Perez, S., Mariani, M. C., Corradelli, C., et al. (2011). Habitat overlap between sympatric European hares (Lepus europaeus) and Eastern cottontails (Sylvilagus floridanus) in northern Italy. Acta Theriologica, 56, 53-61. http://dx.doi.org/10.1007/s13364-010-0005-x 
Ward, K. J., Stedman, R. C., Luloff, A. E., Shortle, J. S., \& Finley, J. C. (2008). Categorizing deer hunters by typologies useful to game managers: A latent-class model. Society and Natural Resources, 21(3), 215-229.

Zanet, S., Palese, V., Trisciuoglio, A., Alonso, C. C., \& Ferroglio, E. (2013). Encephalitozoon cuniculi, Toxoplasma gondii and Neospora caninum infection in invasive eastern cottontail rabbits Sylvilagus floridanus in northwestern Italy. Veterinary Parasitology, 197, 682-684. http://dx.doi.org/10.1016/j.vetpar.2013. 05.014

\section{Tables}

Table 1 - Structure of the questionnaires

\begin{tabular}{|l|l|l|}
\hline Section & Question & Type \\
\hline 1 - Demographic features & $\begin{array}{l}\text { Date, place, age, gender, } \\
\text { occupation, municipality of } \\
\text { residence, first hunting district, } \\
\text { second hunting district }\end{array}$ & Open-ended \\
\hline 2- Type of hunting & $\begin{array}{l}\text { Indicate the type of your } \\
\text { regional hunting permit } \\
\text { (A,B,C,D) }\end{array}$ & Multiple-choice \\
\hline $\begin{array}{l}\text { Do you also have a permit for } \\
\text { wild boar hunting? }\end{array}$ & Dichotomous \\
& $\begin{array}{l}\text { Do you also have a permit for } \\
\text { deer stalking? }\end{array}$ & Dichotomous \\
\hline $\begin{array}{l}\text { Do you also have a permit for } \\
\text { lethal control schemes? }\end{array}$ & Dichotomous \\
\hline & $\begin{array}{l}\text { Do you volunteer for you } \\
\text { hunting district (e.g } \\
\text { environmental schemes)? }\end{array}$ & Dichotomous \\
\hline $\begin{array}{l}\text { Do you also hunt on private } \\
\text { estates? }\end{array}$ & Dichotomous \\
\hline $\begin{array}{l}\text { Indicate the best management } \\
\text { strategy, for a decreasing game } \\
\text { species (hunting ban, } \\
\text { long-term recovery plan, } \\
\text { seasonal restocking after the } \\
\text { hunting season, seasonal } \\
\text { restocking before the hunting } \\
\text { season) }\end{array}$ & Multiple-choice \\
\hline
\end{tabular}




\begin{tabular}{|c|c|c|}
\hline & $\begin{array}{l}\text { What would you do if your } \\
\text { favourite game species would } \\
\text { disappear from your hunting } \\
\text { estate? }\end{array}$ & Open-ended \\
\hline \multirow[t]{7}{*}{3 - Hares and cottontails } & $\begin{array}{l}\text { Do you know the Eastern } \\
\text { cottontail? }\end{array}$ & Dichotomous \\
\hline & $\begin{array}{l}\text { Hunting bag: number of hares } \\
\text { killed per season }\end{array}$ & Close-ended \\
\hline & $\begin{array}{l}\text { Hunting bag: number of } \\
\text { cottontails killed per season }\end{array}$ & Close-ended \\
\hline & $\begin{array}{l}\text { Which is your favourite game: } \\
\text { hares, cottontails or both? }\end{array}$ & Close-ended \\
\hline & Why do you hunt hares? & Multiple-choice \\
\hline & Why do you hunt cottontails? & Multiple-choice \\
\hline & $\begin{array}{l}\text { Do you record the cottontails } \\
\text { you kill? }\end{array}$ & Dichotomous \\
\hline \multirow[t]{8}{*}{$\begin{array}{l}4 \text { - Knowledge and beliefs } \\
\text { about cottontails and hares }\end{array}$} & $\begin{array}{l}\text { Is the Eastern cottontail a } \\
\text { native species? }\end{array}$ & Dichotomous \\
\hline & $\begin{array}{l}\text { Which is its geographical } \\
\text { origin? }\end{array}$ & Open-ended \\
\hline & $\begin{array}{l}\text { Is the Eastern cottontail an } \\
\text { edible game species? }\end{array}$ & Dichotomous \\
\hline & $\begin{array}{l}\text { Which is the scientific status of } \\
\text { the Eastern cottontail? }\end{array}$ & Close-ended \\
\hline & $\begin{array}{l}\text { Which is the general } \\
\text { population trend of hares? }\end{array}$ & Close-ended \\
\hline & $\begin{array}{l}\text { Which is the general } \\
\text { population trend of } \\
\text { cottontails? }\end{array}$ & Close-ended \\
\hline & $\begin{array}{l}\text { Which is the likelihood of a } \\
\text { negative impact of cottontails } \\
\text { on hares or on the } \\
\text { environment? }\end{array}$ & 4-points Likert scale \\
\hline & $\begin{array}{l}\text { Which type of impact do you } \\
\text { think cottontails may have on } \\
\text { hares or on the environment? }\end{array}$ & Open-ended \\
\hline \multirow[t]{2}{*}{$\begin{array}{l}5 \text { - Attitudes towards cottontail } \\
\text { management }\end{array}$} & $\begin{array}{l}\text { Would you support the } \\
\text { eradication of cottontails? }\end{array}$ & Dichotomous \\
\hline & $\begin{array}{l}\text { Provide a reason for } \\
\text { supporting/opposing to the } \\
\text { eradication of cottontails }\end{array}$ & Open-ended \\
\hline
\end{tabular}


Table 2 - Final set of questions retained for data analysis

\begin{tabular}{|c|c|c|}
\hline Question & Proportion of missing data & Type \\
\hline $\begin{array}{l}\text { Do you know the Eastern } \\
\text { cottontail? }\end{array}$ & 0.10 & Dichotomous \\
\hline $\begin{array}{l}\text { Hunting bag: number of hares } \\
\text { killed per season }\end{array}$ & 0.23 & Close-ended \\
\hline $\begin{array}{l}\text { Hunting bag: number of } \\
\text { cottontails killed per season }\end{array}$ & 0.28 & Close-ended \\
\hline $\begin{array}{l}\text { Which is your favourite game: } \\
\text { hares, cottontails or both? }\end{array}$ & 0.36 & Close-ended \\
\hline Why do you hunt hares? & 0.47 & Multiple-choice \\
\hline Why do you hunt cottontails? & 0.47 & Multiple-choice \\
\hline $\begin{array}{l}\text { Which is the general population } \\
\text { trend of hares? }\end{array}$ & & Close-ended \\
\hline $\begin{array}{l}\text { Which is the general population } \\
\text { trend of cottontails? }\end{array}$ & & Close-ended \\
\hline $\begin{array}{l}\text { Which factors negatively affect } \\
\text { the abundance of hares? }\end{array}$ & 0.19 & Multiple-choice \\
\hline $\begin{array}{l}\text { Are you favourable to release } \\
\text { cottontail in the environment? }\end{array}$ & 0.10 & Dichotomous \\
\hline $\begin{array}{l}\text { Do you record the cottontails } \\
\text { you kill? }\end{array}$ & 0.45 & Dichotomous \\
\hline $\begin{array}{l}\text { Is the Eastern cottontail a native } \\
\text { species? }\end{array}$ & 0.47 & Dichotomous \\
\hline $\begin{array}{l}\text { Which is its /geographical } \\
\text { origin? }\end{array}$ & 0.82 & Open-ended \\
\hline $\begin{array}{l}\text { Is the Eastern cottontail an } \\
\text { edible game species? }\end{array}$ & 0.28 & Dichotomous \\
\hline $\begin{array}{l}\text { Which is the scientific status of } \\
\text { the Eastern cottontail? }\end{array}$ & 0.26 & Close-ended \\
\hline $\begin{array}{l}\text { Which is the likelihood of a } \\
\text { negative impact of cottontails } \\
\text { on hares or on the environment? }\end{array}$ & 0.17 & 4-points Likert scale \\
\hline $\begin{array}{l}\text { Which type of impact do you } \\
\text { think cottontails may have on } \\
\text { hares or on the environment? }\end{array}$ & 0.46 & Open-ended \\
\hline $\begin{array}{l}\text { Would you support the } \\
\text { eradication of cottontails? }\end{array}$ & 0.28 & Dichotomous \\
\hline Provide a reason for & 0.47 & Open-ended \\
\hline
\end{tabular}


supporting/opposing to the eradication of cottontails.

Table 3 - Comparison among individual beliefs about a negative impact of Eastern cottontails on native European hares in the different study areas, measured on a 4-points Likert scale

\begin{tabular}{|l|l|l|l|}
\hline \multicolumn{4}{|l|}{ Which is the likelihood of a negative impact of cottontails on hares or on the environment? } \\
\hline Geographical area & Sample size & Mean & Standard deviation \\
\hline Lucca & 10 & 2.60 & 0.97 \\
\hline Mugello & 33 & 1.91 & 1.04 \\
\hline Padule di Fucecchio & 73 & 1.63 & 0.86 \\
\hline Pisa & 10 & 2.50 & 1.35 \\
\hline Pistoia & 30 & 2.10 & 1.12 \\
\hline Val di Nievole & 59 & 2.51 & 1.21 \\
\hline One-Way ANOVA & $\mathrm{F}=5.5475$ & $\mathrm{df}=5$ & $\mathrm{p}<0.01$ \\
\hline Bartlett's test & $\mathrm{K}^{2}=9.2631$ & $\mathrm{df}=5$ & $\mathrm{p}<0.01$ \\
\hline
\end{tabular}

\section{Figures}

Fig.1 - Study area: the municipalities involved in the survey, divided in six geographical areas. 


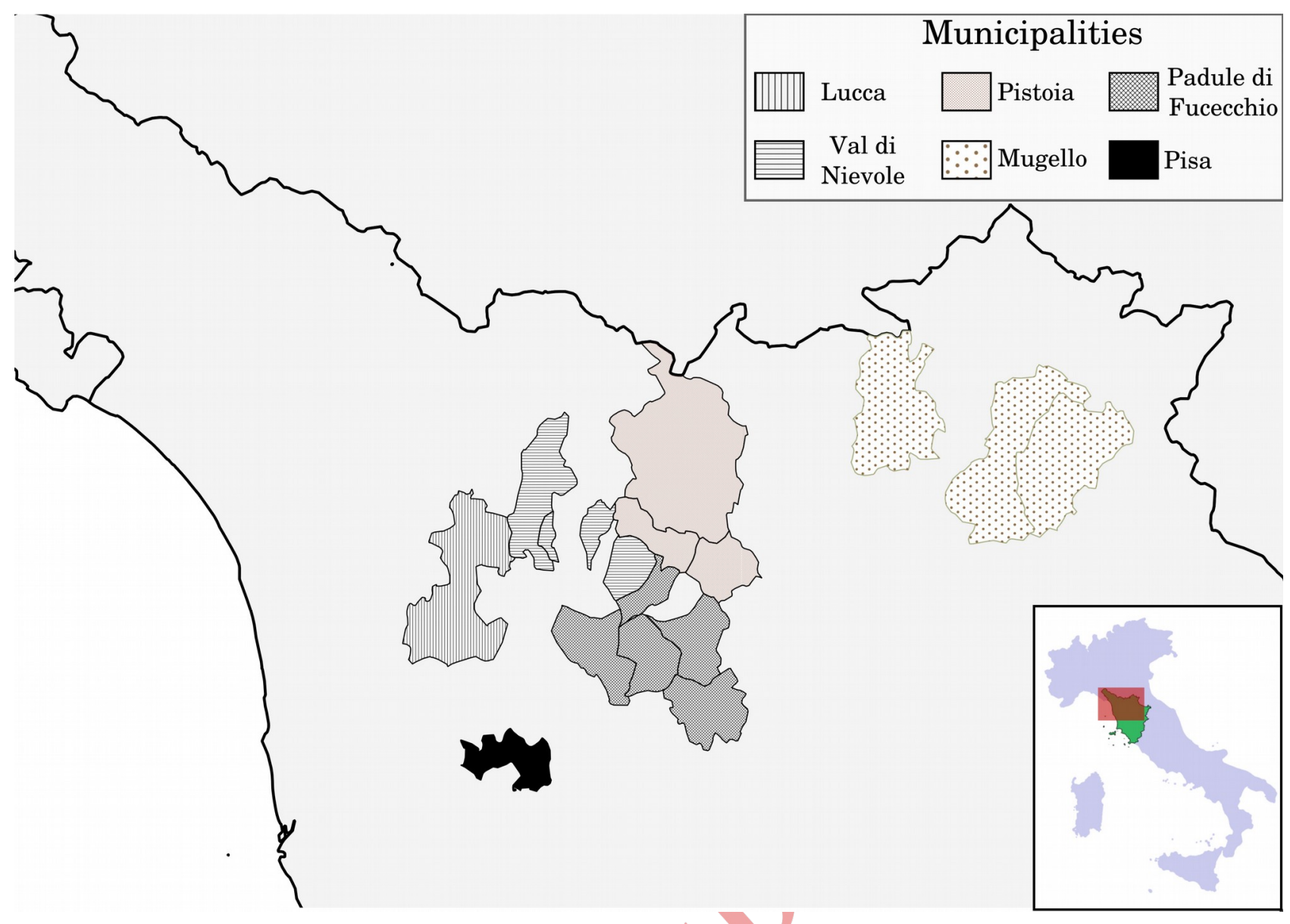

Fig.2 - Perceived population trends of hares (grey) and cottontails (black). 


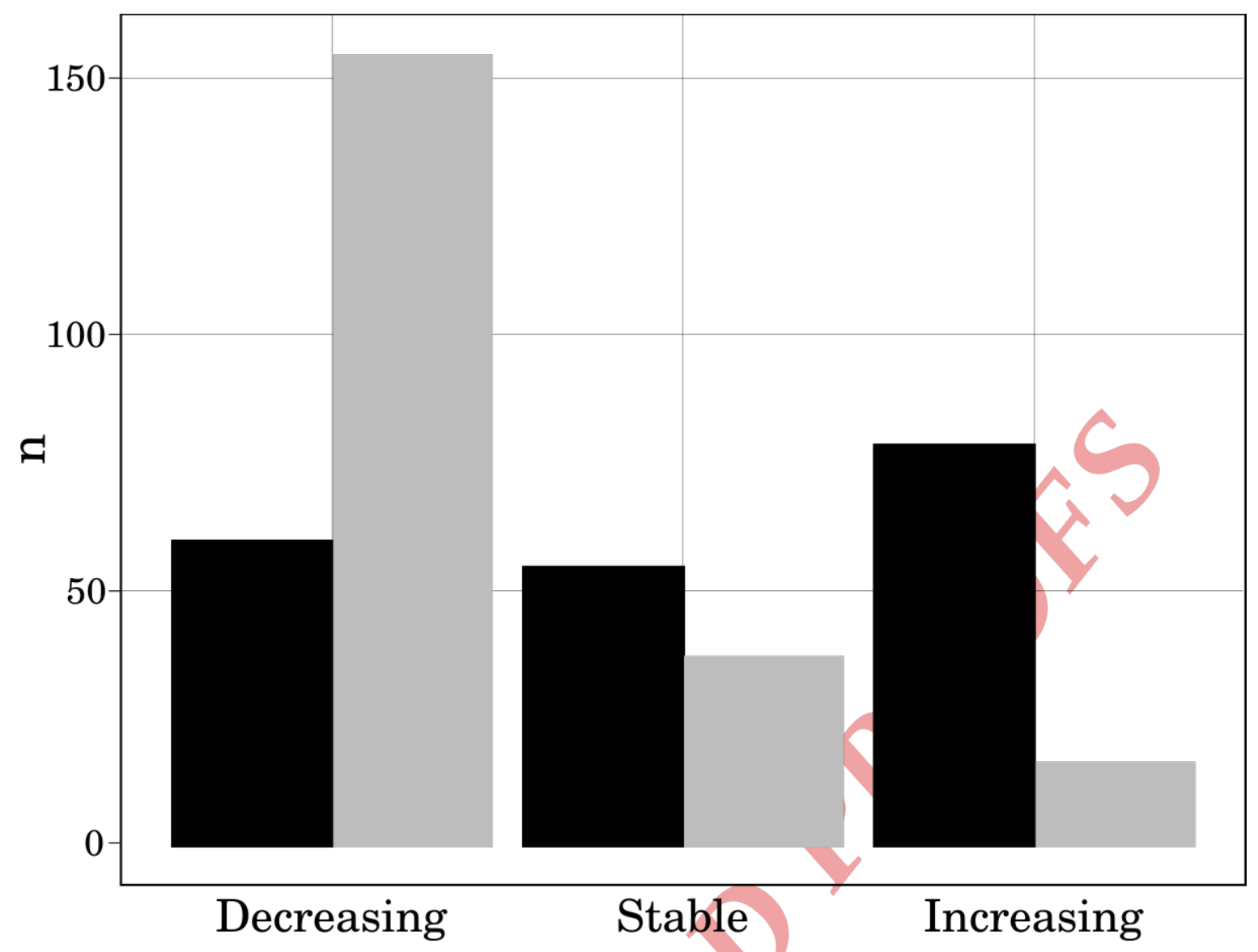

Fig.3 - Attitudes towards the eradication and beliefs about negative impacts of cottontails.

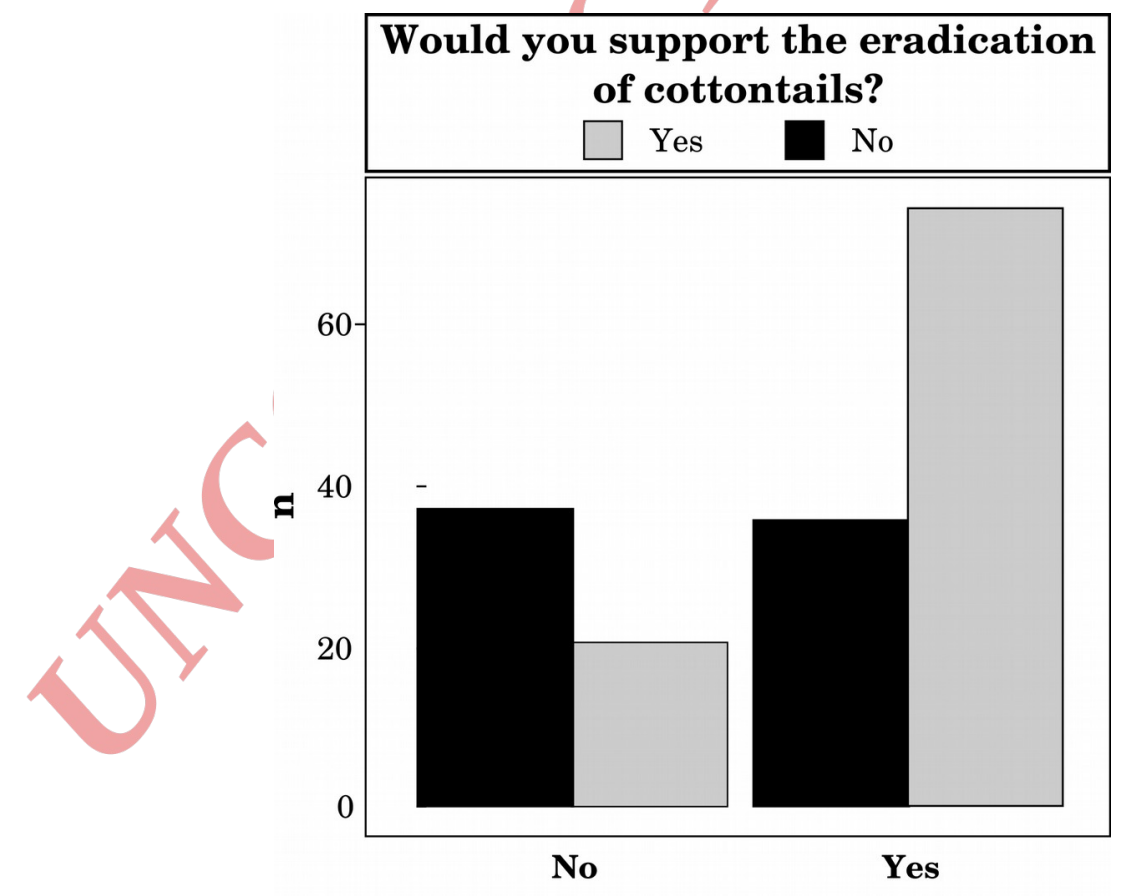

Negative impact of cottontails 
Fig.4 - Perceived population decline of hares and support to the releasing and hunting of cottontails.
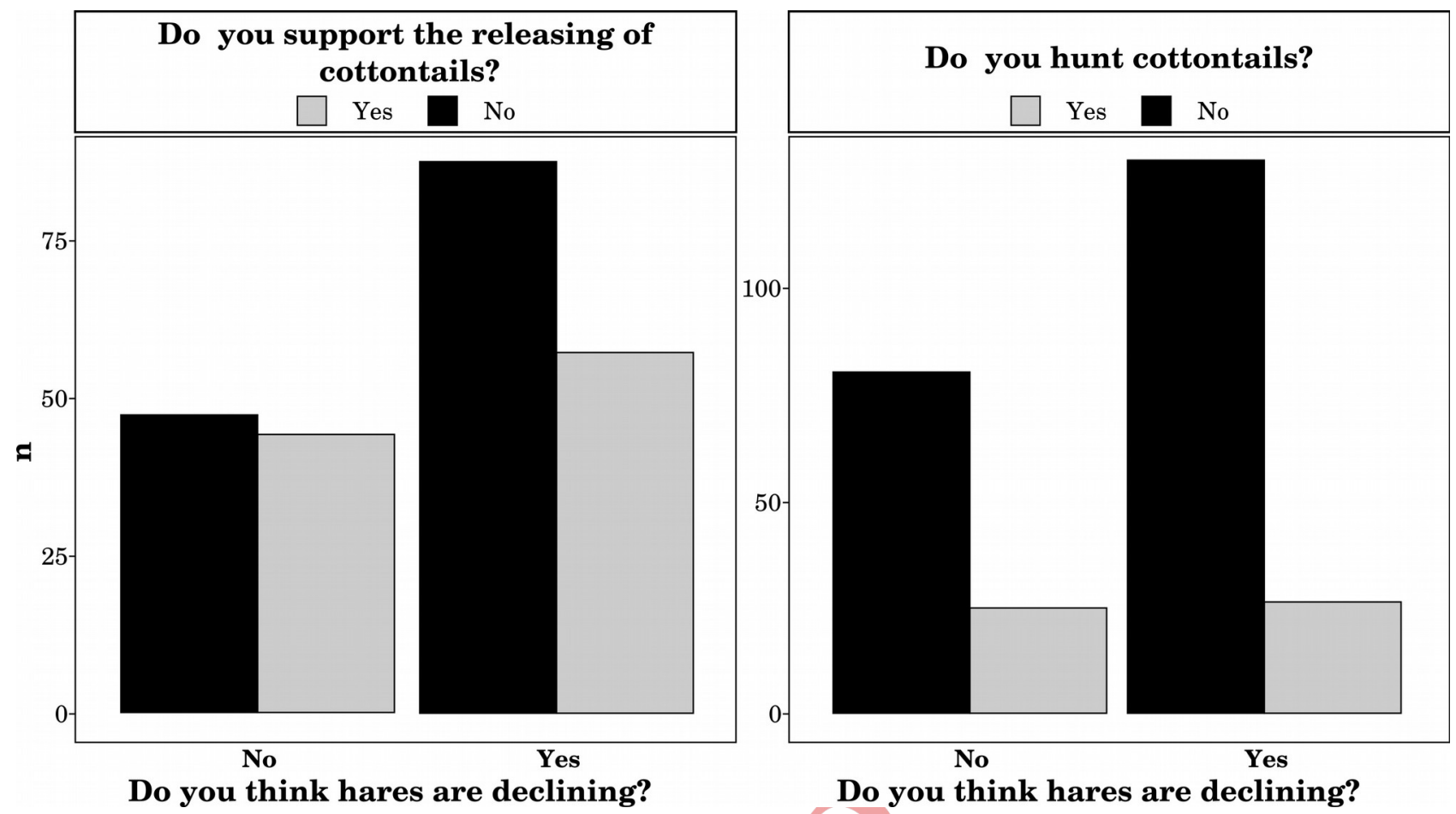

Fig.5 - Differences between four geographical areas: beliefs about a negative impact and about the taxonomic status of cottontails..
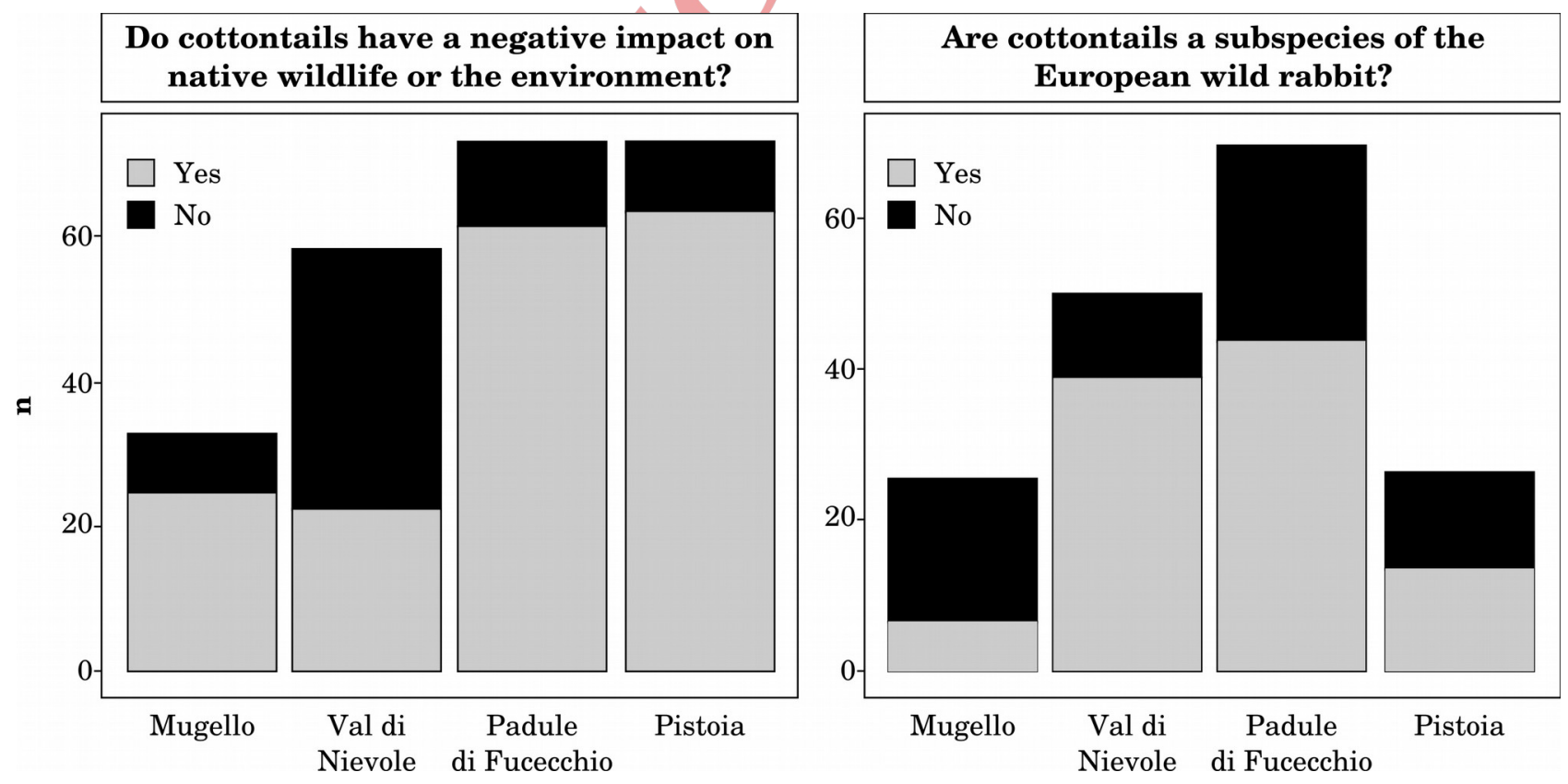
Fig.6 - Reasons for hare (grey) and cottontail (black) hunting.

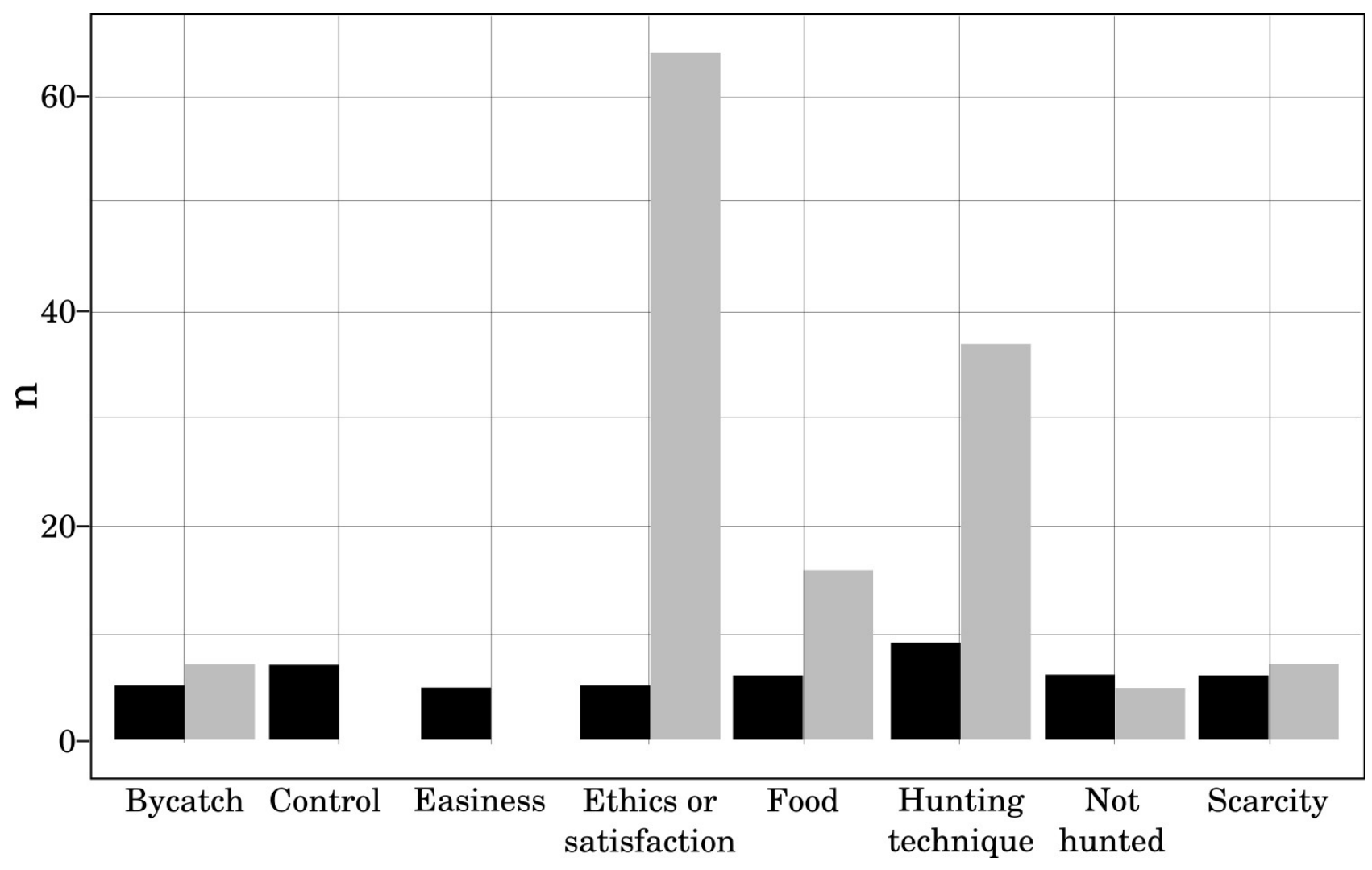




\section{Supplementary Materials}

S1 - Cottontails sold at a local game fair in Tuscany (picture provided by Marco Ferretti)
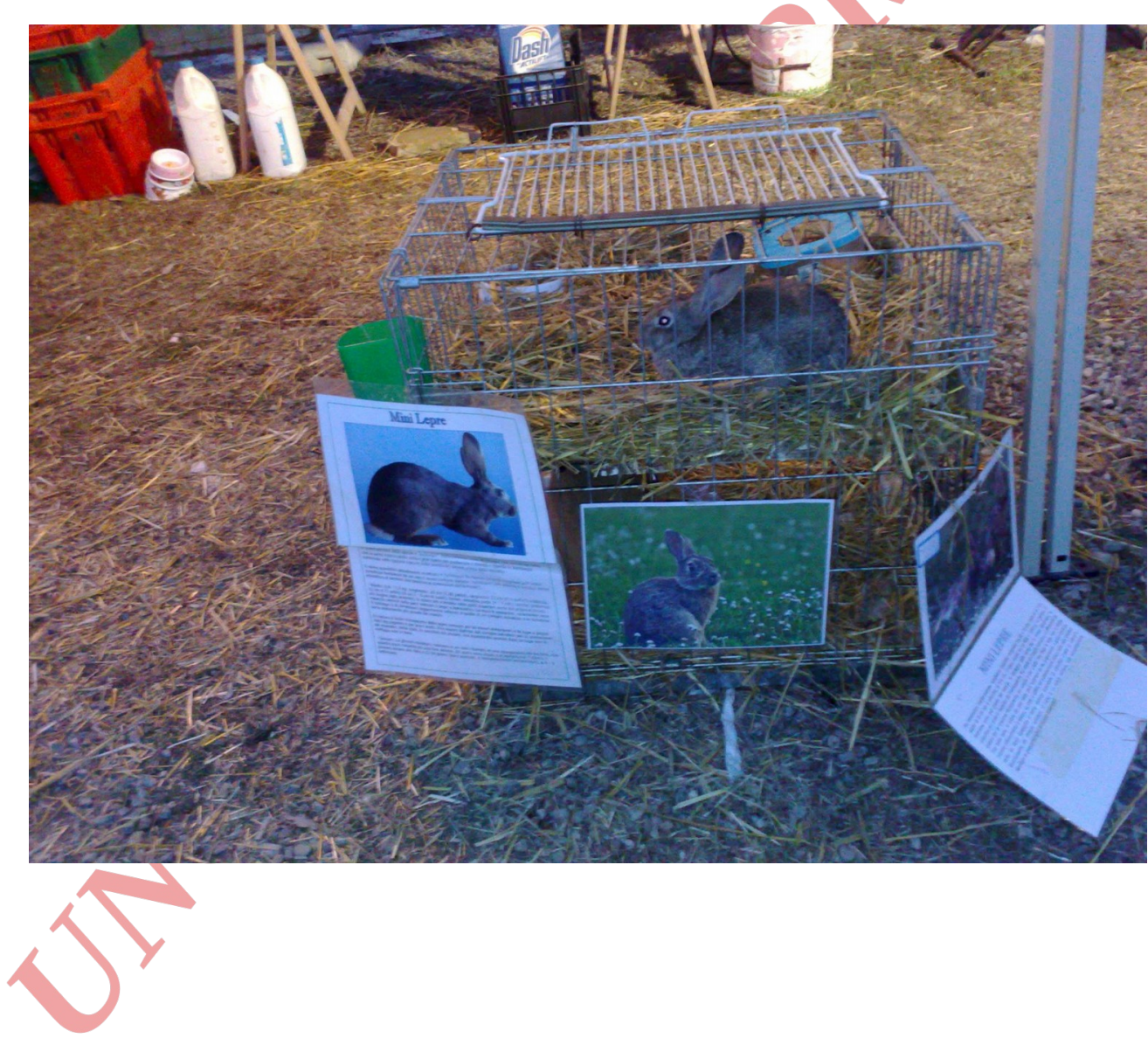